Jurnal Scripta Teologi dan Pelayanan Kontekstual
ISSN 2086-5368 (Print)
ISSN
Http://ejournal.stte.ac.id
Vol.3, No.2, pp. 129-139, 2018

\title{
Analisis Pertumbuhan Gereja Mula-mula Dalam Kisah Para Rasul dan Relevansinya Bagi Gereja Masa Kini
}

\begin{tabular}{|c|c|}
\hline \multicolumn{2}{|c|}{ STTEbenhaezer Tanjung Enim, siagian.rustam.103@gmail.com } \\
\hline INFO ARTIKEL & ABSTRAK \\
\hline Sejarah & Pembahasan tentang pertumbuhan gereja selalu menjadi perhatian \\
\hline Diterima : 03 Nov 2018 & harapan bisa diterapkan di dalam gereja masing-masing agar \\
\hline Direvisi : 08 Nov 2018 & pertumbuhan bisa tercapai secara maksimal. Tetapi sesungguhnya \\
\hline Disetujui: 15 Nov 2018 & dasar pertumbuhan gereja sudah disampaikan kepada gereja dalam \\
\hline $\begin{array}{l}\text { Dipublikasi: } 28 \text { Nov } \\
2018\end{array}$ & $\begin{array}{l}\text { kitab Kisah Para Rasul, karena itu tulisan ini akan menelusuri prinsip- } \\
\text { prinsip pertumbuhan gereja dari kitab Kisah Para Rasul dan dengan }\end{array}$ \\
\hline & narapan prınsıp-prınsıp Itu menjaaı masukan bagı gereja masa kını. \\
\hline
\end{tabular}

keyword one, keyword two, keyword three.

Keywords:

keyword one, keyword two, keyword three.

\begin{abstract}
Discussions about church growth always come to the attention of church leaders everywhere. Various theories are learned with the hope that they can be applied in their respective churches so that growth can be achieved to the maximum. But actually the basis for the growth of the church has been conveyed to the church in the book of Acts, therefore this paper will explore the principles of church growth from the book of Acts and hopefully these principles will be input for the church today.
\end{abstract}

\section{Pendahuluan}

Setiap gereja dimana saja selalu terus berjuang untuk terus tumbuh dan berkembang. Pertumbuhan yang terus diperjuangkan itu berupa pertumbukan kuantitas dan kualitas. Karena itu para pelayan dan semua orang yang terlibat dalam gereja akan terus berjuang untuk mencapai pertumbuhan yang maksimal. Karena itu berbagai usaha terus dilakukan untuk menjaga agar pertumbuhan itu terus berkesinambungan. Semua sumber daya yang ada diinventarisasi, disatukan dan dikelola secara baik untuk mendorong terjadinya pertumbuhan. Tetapi harus diakui pertumbuhan tidak semudah membuat program-program pertumbuhan jemaat. Karena sering terjadi program-progam untuk pertumbuhan sudah dibuat dan dilaksanakan tetapi pertumbuhan belum tercapai sesuai dengan apa yang diharapkan. Gereja yang diharapkan bertumbuh, malah seperti jalan ditempat, tidak ada sesuatu yang berobah. 
Dibeberapa tempat ada gereja yang kelihatannya sukar sekali untuk bertumbuh, karena yang terjadi bukan kemajuan tetapi justru kontra-produktif, sehingga gereja itu makin mengalami kemunduran. Jumlah jemaat makin menurun, pengunjung ibadah minggu makin berkurang, tidak ada sesuatu yang dinamis dalam kegiatan mereka, keadaan yang terjadi menunjukkan gereja itu seperti tidak bersemangat untuk melanjutkan pertumbuhan. Maka tidak heran ada bangunan gereja yang megah tetapi jemaat yang beribadah sangat sedikit. Tentu keadaan gereja seperti itu amat memprihatinkan. Kalau gereja-gereja Indonesia tidak hati-hati, maka bisa saja terjadi akan makin banyak gereja yang mengalami kemunduran. Gereja-gereja di Indonesia mesti waspada terhadap keadaan gereja di Indonesia

Pada zaman ini, gereja sedang menghadapi serbuan materialisasi, sekularisasi, postmodernisme, faham kekafiran melalui media cetak dan elektonik. Oleh kemajuan teknologi, setiap orang percaya begitu dekat dengan semua pengaruh dari dunia ini. Dan oleh pengaruh itu, orang percaya atau gereja mengalami masalah yang serius. Dalam berbagai laporan yang didengar bahwa banyak gereja yang sudah mengalami peresapan dunia dalam gereja. Karena itu tidak sedikit gereja yang telah mengalami disorientasi. Pertumbuhan bukan lagi menjadi perhatian utama, tetapi pada hal-hal yang bersifat lahiriah. Bagi kebanyakan gereja yang penting adalah semua kegiatan gerejawi berjalan baik, tanpa gangguan, semua aman dan teratur, kas gereja makin banyak dan sejalan dengan itu penambahan jumlah sarana pra-sarana makin banyak, sementara itu kemajuan rohani jemaat tidak lagi menjadi fokus perhatian, sehingga pertumbuhan jemaat sedang jalan ditempat atau malah cenderung mundur.

Karena itu tidak heran gereja berlomba-lomba mendirikan bangunan gereja yang megah dan berjuang untuk mengisi banguan itu dengan jumlah jemaat yang secara kuantitas banyak. Maka gereja yang satu dengan lain saling berebut jemaat. Dalam perkembangan itu muncullah istilah yang tidak asing bagi kebanyakan gereja yaitu mencuri domba dari kandang gembala yang lain. Antar gereja menjadi saling mencurigai dan malah saling merendahkan. Tentu kondisi ini akan melemahkan kesaksian gereja ditengah-tengah masyarakat. Gereja sebagai lembaga rohani kehilangan kekuatannya untuk menyatakan kebenaran dalam kehidupan berbangsa dan bernegara.

Kemudian dalam kenyataan lain, kondisi gereja yang lemah itu semakin sulit, karena para pemimpin atau pelayan dalam gereja pun, ikut-ikutan membawa pola-pola dunia dalam gereja. Pada hal sebagai wakil Allah, mereka mempunyai tanggungjawab untuk menyatakan kebenaran kepada umat, tidak hanya melalui khotbah tetapi juga dengan memberi contoh yang hidup kepada jemaat. Namun sangat disayangkan justru mereka menjadi kelompok yang paling rentan dengan pengaruh dunia dalam gereja. Ada banyak pelayan gereja yang menyalahgunakan jabatannya untuk kepentingan pribadi. Maka untuk mendapatkan jabatan tertentu, mereka menggunakan cara-cara dunia, misalnya melalui intimidasi tertentu atau dengan menggunakan uang. Karena dengan memperoleh jabatan itu, mereka merasa menjadi terhormat dan digaji dengan nilai uang yang lebih banyak. Keadaan seperti ini sangat disayangkan, karena jika tidak segera ada perobahan-perobahan yang mendasar, gereja seperti itu secara perlahan akan kehilangan esensisnya sebagai gereja.

Lalu dari penjelasan diatas, timbul pertanyaan mungkinkah gereja sebagai lembaga milik Allah dapat mengalami perobahan, perbertumbuhan di tengah-tengah dunia yang penuh dengan faham kekafiran, di tengah-tengah dunia yang makin gelap 
dewasa ini. Kalau gereja masih dapat bertumbuh di tengah kondisi yang sulit itu, apakah usaha yang dapat dilakukan agar gereja dapat terus bertumbuh meskipun dunia terus menggempur gereja dengan segala upaya mendorongnya untuk mundur. Pokok-pokok pikiran yang dikemukakan dalam pertanyaan itu menjadi perhatian utama dalam tulisan ini.

\section{Metode Penelitian}

Dalam penulisan ini penulis menggunakan metode deskriftif-bibliologis. Metode deskriftif adalah suatu metode pentlitian yang meneliti sekelompok manusia, suatu objek, suatu kondisi, suatu system pemikiran ataupun suatu kilas peristiwa masa sekarang. Adapun tujuan penelitian ini adalh membuat deskripsi, gambaran atau lukisan secara sistematis, factual dan akurat mengenai fakta-fakta, sifat-sifat serta hubungan antar fenomena yang diteliti.

Pengumpulan data yang dilakukan dengan cara penelitian menanalisis literatur dan penelaan dokomen.

\section{Hasil Dan Pembahasan}

\section{A. Kisah Para Rasul Sebagai Suatu Kitab Sejarah}

Kalimat pembukaan pada kitab Lukas mengindikasikan bahwa tujuan utama kitab Lukas adalah bersifat sejarah dan tentu dapat dipandang juga sebagai tujuan utama penulisan kitab Kisah Para Rasul. Dan jika diperhatikan, isi kitab Kisah Para Rasul cukup jelas terlihat bahwa kitab ini disusun dengan peristiwa-peristiwa yang teratur. Walaupun harus diakui bahwa dalam mencatat peristiwa-peristiwa sejarah, Lukas berbeda dengan sejarawan modern. Lukas lebih menaruh perhatian kepada peristiwa yang mendalam baginya. Lukas sadar bahwa dia tidak dapat menghindari getaran peristiwa-peristiwa ilahi yang dilihat atau didengarnya.

\section{B. Kisah Para Rasul Sebagai Suatu Apologetika}

Beberapa ahli berpendapat bahwa Kisah Para Rasul memiliki tujuan Apologetika. Pada abad pertama agama Yahudi dianggap sebagai agama resmi oleh pemerintah Romawi. Kemudian pada permulaan perkembangan kekristenan, waktu rasul-rasul memulai pelayanannya, ajaran rasul-rasul dianggap sebagai suatu variasi atau mazhab baru dalam agama Yahudi, karena itu kekristenan masih belum mendapat perlawanan dari pemerintahan Romawi. Tetapi dalam perkembangan selanjutnya, pengajaran para rasul mulai dianggap agama baru, karena itu kekristenan mengalami berbagai hambatan dari pemerintahan Romawi. Dan untuk menanggapi situasi ini, para ahli melihat Kisah Para Rasul adalah sebagai pembelaan terhadap kekristenan. Nampak penulis hendak menunjukkan bahwa agama Yahudi erat kaitannya dengan kekristenan. Misalnya, Paulus dan Timotius masih melakukan tuntunan hukum dalam agama Yahudi. Bahkan lebih jauh, penulis sedang menekankan bahwa Kekristenan merupakan kelanjutan agama Yahudi. Karena itu hak orang Kristen berkumpul, menyembah Tuhan dan menyiarkan kepercayaan mereka seharusnya dilindungi pemerintah Romawi sama seperti yang dinikmati agama Yahudi.

Dari dua penjelasan di atas tentang tujuan penulisan kitab Kisah Para Rasul, terdapat beberapa hal yang perlu dipertanyakan. Kalau tujuan Kisah Para Rasul ditulis adalah sebagai suatu kisah sejarah dan untuk tujuan apologetika, mengapa ada bagian yang perlu dalam pelayanan para rasul tidak dicatat. Misalnya kalau Kisah Para Rasul 
adalah sebagai suatu kisah sejarah, mengapa perjalanan Paulus ke Arabia (Gal 1:17) tidak dicatat dan juga pelayanan rasul-rasul lain tidak disampaikan. Dan kalau Kisah Para Rasul sebagai suatu apologetika, mengapa ada bagian kisah yang tidak mendukung apologetika diutarakan, seperti kapal Paulus yang kandas disampaikn secara detail (Kisah 27:14-44). Karena itu ada usulan lain yang perlu diperhatikan sebagai tujuan penulis Kisah Para Rasul untuk menyampaikan kisahnya kepada semua gereja sepanjang zaman.

\section{Kisah Para Rasul Untuk Menjelaskan Pertumbuhan Gereja}

Pendapat ini cocok dengan pernyataan Yesus Kristus dalam Kisah Rasul 1:8, sebagai patron perkembangan kesaksian para Rasul yang dimulai dari Yesusalem sampai ke ujung dunia. Dan jika diperhatikan semua peristiwa yang dicatat dalam Kisah Para Rasul menyatakan tujuan ini. Bahkan perhatian penulis dalam beberapa bagian Kisah Para Rasul menunjukkan bahwa penulis hendak menekankan perkembangan gereja mula-mula, sehingga tidak berlebihan jika dikatakan bahwa tujuan Kisah Para Rasul adalah hendak menyampaikan pertumbuhan gereja oleh kesaksian para rasul dan orang percaya dengan kuasa Roh Kudus. Karena itu pertumbuhan gereja dalam Kisah Para Rasul adalah patron bagi gereja sepanjang zaman tentang bagaimana agar gereja dapat bertumbuh dari kelompok yang kecil, menjadi besar dan kuat meskipun menghadapi kesulitan, penderitaan yang buruk tetapi tetap eksis dan maju mekar menjangkau dunia bagi kemuliaan Tuhan. Berdasarkan tujuan itu, maka berikut akan disampaikan Garis Besar Kisah Para Rasul.

\section{Bukti Pertumbuhan Gereja Mula-Mula Dari Laporan Kisah Para Rasul}

Ada beberapa fakta yang jelas yang menunjukkan bahwa Kisah Para Rasul menjelaskan pertumbuhan gereja mula-mula. Ada beberapa laporan yang disampaikan oleh Kisah Rasul tentang pertumbuhan gereja mula-mula. Laporan pertama terlihat dalam Kisah 2:47, dan tiap-tiap hari Tuhan menambahkan jumlah mereka dengan orang yang diselamatkan. Pertambahan yang terjadi dihubungkan dengan orang yang diselamatkan. Artinya pertambahan yang terjadi bukan secara lahiriah tetapi secara rohani, jumlah yang bertambah itu dihitung dari mereka yang mengalami keselamatan dalam Kristus. Kedua, pada Kisah 4:4, tetapi di antara orang yang mendengar ajaran itu banyak yang menjadi percaya, sehingga jumlah mereka menjadi kira-kira lima ribu orang laki-laki. Penjelasan dalam ayat ini disertai dengan laporan jumlah mereka yang percaya, suatu jumlah yang besar dari suatu kumpulan yang baru berkembang. Ketiga, pada ada Kisah 6:7, Firman Allah makin tersebar dan jumlah murid di Yerusalem makin bertambah banyak, juga sejumlah besar imam menyerahkan diri dan percaya. Pada laporan ini bukan saja soal jumlah orang percaya yang dilaporkan makin bertambah tetapi juga kelompok sulit untuk percaya pun yaitu para imam banyak yang menjadi percaya. Keempat, selama beberapa waktu jemaat di seluruh Yudea, Galilea, dan Samaria berada dalam keadaan damai. Jemaat itu dibangun dan hidup dalam takut akan Tuhan. Jumlahnya makin bertambah besar oleh pertolongan dan penghiburan Roh Kudus (Kisah 9:31). Kelima, Maka Firman Tuhan makin tersebar dan makin banyak didengar orang (Kisah 12:24). Keenam, Demikianlah jemaat-jemaat diteguhkan dalam iman dan makin lama makin bertambah besar jumlahnya (Kisah 16:5). Ketujuah, pada Kisah 19:20, dengan jalan ini makin tersiar Firman Tuhan dan makin berkuasa. Laporanlaporan pada ayat-ayat yang sudah disebutkan menunjukkan bahwa pertumbuhan 
jemaat mula-mula itu sangat pesat dan signifikan. Dimulai dengan laporan pertambahan yang ditunjukkan dengan angka, tetapi kemudian pertambahan jumlah orang percaya tidak lagi dengan angka tertentu tetapi dengan makin banyak dan makin bertambah. Suatu pertambahan atau perkembangan yang menakjubkan, dimana jemaat mula-mula itu dimulai dengan kelompok yang kecil tetapi waktu yang tidak terlalu lama jumlah mereka sudah mencapai ribuan pengikut.

Karena itu dari pernyataan ayat-ayat dari Kisah Para Rasul di atas menyatakan bahwa pertumbuhan gereja mula-mula yang dimulai dari Yerusalem dan terus berkembang secara signifikan ke tempat-tempat yang lebih luas. Dan perkembangannya pun menjangkau daerah-daerah baru, suku-suku bukan Yahudi dan semua lapisan masyarakat, walaupun lebih banyak masyarakat biasa. Perkembangan itu sangat mencengangkan, karena dalam jangka waktu yang tidak terlalu lama, Injil sudah menyeberang ke Asia kecil dan sebagian Eropa selatan. Karena itu prinsip dan strategi perkembangan gereja mula-mula perlu menjadi perhatian gereja zaman ini. Dengan memahami perinsip dan strategi itu, maka diharapkan dapat diterapkan di gereja-gereja Tuhan pada masa sekarang ini.

\section{E. Prinsip Dan Strategi Pertumbuhan Gereja Dari Kisah Para Rasul}

\section{Dasar Strategi Pertumbuhan Gereja Bersumber Dari Kuasa Roh Kudus (Kisah 1:8)}

Bahwa daerah pertumbuhan dan pelayanan gereja adalah seluruh dunia, yang dimulai dari Yerusalem dan sampai ke ujung bumi. Hal ini yang menjadi dasar strategi pertumbuhan gereja, yang ditugaskan menjangkau seluruh dunia. Pekerjaan besar itu hanya mungkin dilakukan gereja oleh pertolongan atau kuasa Roh Kudus. Gereja tidak akan mungkin bertumbuh dan berkembang dengan kekuatan dari diri sendiri. Hanya oleh kuasa Roh Kudus, gereja mempunyai kuasa untuk menjadi saksi, membawa manusia yang berdosa masuk dalam gereja dan menjadi umat Tuhan, menjadi anggota gereja yang membawa berkat bagi banyak orang. Prinsip ini menjadi dasar yang penting bagi gereja untuk bertumbuh. Artinya gereja hanya bisa bertumbuh dan berkembang, hal itu sangat bergantung kepada kuasa Roh Kudus bukan kepada unsurunsur manusia, fisik dalam gereja yang sering menjadi pokok perhatian gereja dimasa kini.

\section{Inti Berita Yang Dibawa Gereja Ke Dalam Dunia (Kisah 2:36, 3:11-26).}

Dalam usaha gereja menjangkau dunia, membawa sebanyak mungkin orang untuk percaya kepada Yesus Kristus, maka inti beritanya adalah tentang karya keselamatan yang dikerjakan Yesus Kristus melalui kematian dan kebangkitanNya. Gereja yang kehilangan beritanya adalah gereja yang sakit dan tentu sulit bagi gereja yang kehilangan beritanya dapat bertumbuh dengan baik. Karena itu pokok pikiran ini menjadi prinsip yang sangat penting dan harus dipelihara oleh gereja. Berita Injil adalah berita utama yang harus terus menerus disuarakan atau diberitakan gereja kepada dunia. Berita itu yang dapat membawa sebanyak mungkin orang percaya kepada Tuhan Yesus dan yang hidupnya bisa berobah. Karena itu gereja tidak boleh menyimpan berita kesukaan ini, sebab hanya dengan berita itu jumlah orang percaya secara signifikan bisa makin bertambah 


\section{Pertumbuhan Gereja Bergantung Pada Keterbukaan Kepada Pekerjaan Roh Kudus}

(2:1-12, 4:31, 13:2-4)

Hal ini sesuai dengan pernyataan Tuhan Yesus dalam Yohanes 16:4b-15, bahwa Roh Kudus mempunyai peran yang sangat sentral dalam kehidupan gereja dan dalam kesaksian gereja kepada dunia ini. Karena itu gereja yang terbuka kepada pekerjaan Roh Kudus akan membuat gereja itu mengalami pertumbuhan yang signifikan. Sedangkan gereja yang mulai tertutup atau mengabaikan pekerjaan Roh Kudus akan membuat gereja itu sulit mengalami perkembangan. Jadi pertumbuhan gereja sangat bergantng kepada pekerjaan Roh Kudus. Karena itu gereja dimana saja harus terus membuka diri kepada pekerjaan Roh Kudus. Gereja yang membuka diri kepada pekerjaan Roh Kudus akan mendorong gereja itu makin bertumbuh karena Roh Kudus diberi kesempatan untuk leluasa mengerjakan perkara-perkara rohani terjadi dalam gereja tersebut.

\section{Orientasi Semua Pelayanan Gereja Mula-Mula (Kisah 4:41-47, 4:32-37, 6:1-7)}

Gereja sering keliru dalam hal orientasi pelayanannya. Ada gereja yang orientasi pelayanannya adalah program, atau aktifitas, tetapi gereja yang benar adalah gereja yang berorientasi kepada manusia, yaitu orang percaya yang ada dalam gereja itu dan manusia yang terhilang. Pelayanan jemaat mula-mula jelas sekali memperhatikan keadaaan jemaat, baik secara rohani maupun secara kebutuhan jasmani. Para rasul tidak hanya menekankan pengajaran Firman tetapi memperhatikan jemaat yang mengalami kekurangan, sehingga semua bentuk bantuan yang diterima gereja dari jemaat yang mampu disalurkan atau dinikmati bersama dengan semua jemaat. Kemudian gereja mula-mula tidak hanya puas dengan diri sendiri, tetapi mereka aktif keluar untuk menjangkau manusia yang ada di luar gereja. Dengan demikian jelas sekali semua aktifitas atau program jemaat mula-mula murni demi membina jemaat dan menjangkau manusia yang jauh dari Tuhan.

\section{Strategi Pertumbuhan Gereja Dari Kisah Para Rasul}

Dalam Kisah Para Rasul terdapat juga beberapa bagian nats yang melaporkan tentang strategi yang dipakai jemaat mula-mula untuk berkembang menjadi makin banyak dan makin mempengaruhi banyak orang. Dan strategi itu dapat menjadi pelajaran berharga bagi gereja Tuhan di zaman modern ini. Walaupun situasi gereja pada zaman itu berbeda dengan keadaan gereja pada saat ini tetapi tekanan dunia yang dialami gereja sepanjang zaman selalu mempunyai kesamaan dalam tujuannya namun dalam bentuk yang berbeda-beda. Pendeknya strategi yang digunakan jemaat mula-mula memiliki bobot yang dapat dipakai pada zaman ini. Karena itu berikut akan disampaikan beberapa strategi yang dipakai jemaat mula-mula dalam mengembangkan gereja mereka.

\section{Merumuskan Tujuan Atau Sasaran Pelayanan Gereja (Kisah 1:8)}

Gereja yang dapat bertumbuh adalah gereja yang mempunyai sasaran pelayanan yang jelas. Walaupun pada ayat ini, Tuhan Yesus yang secara langsung mengatakan kalimat dalam Kisah 1:8, tetapi hal itu menjadi patron yang diikuti jemaat mula-mula, sehingga pelayanan mereka tidak hanya di Yerusalem atau hanya kepada bangsa Yahudi saja. Kisah Para Rasul mencatat pelayanan gereja mula-mula berkembang menurut pola dalam Kisah 1:8, mulai dari Yerusalem, kepada orang Yahudi dan bukan 
Yahudi hingga berkembang sampai ke Eropa. Suatu pernyataan tujuan yang sangat jelas dan mudah diingat oleh murid-murid Tuhan Yesus, sehingga para murid bisa selalu mengingatnya bahwa mereka melayani punya tujuan yang jelas yaitu menjangkau Yerusalem hingga ujung bumi.

\section{Aktif Memberitakan Injil (Kisah 2:29-40, 47, 6:7, 8:4, 13:2-4)}

Pada bagian Firman Tuhan dalam ayat-ayat yang disebutkan di atas, menunjukkan jemaat mula-mula sangat aktif memberitakan Injil. Dari ayat-ayat itu jemaat mula-mula memiliki semangat untuk memberitakan Injil kemana pun mereka pergi dan dimana pun mereka berada. Suatu pola hidup yang efektif menjangkau lebih banyak orang yang belum percaya. Dan melalui pemberitaan Injil yang dilakukan jemaat itu merupakan salah satu strategi penting yang memberi dorongan bagi pertumbuhan jemaat mula-mula.

Pada bagian lain jemaat mula-mula juga melakukan pengutusan pelayan-pelayan untuk memberitakan Injil ke daerah-daerah baru yang belum dijangkau oleh Injil. Pada awalnya jemaat mula-mula tidak memahami pentingnya pengutusan ini, tetapi oleh pendidikan dan arahan dari Tuhan melalui penderitaan yang mereka alami dan melalui pengalaman Petrus dengan Kornelius, mereka mulai sadar bahwa Injil juga bagi bangsa-bangsa lain. Karena itu melalui dua peristiwa itu, para rasul dan jemaat di Yerusalem makin memahami bahwa pengutusan Injil perlu bagi bangsa lain sebab mereka pun diperhatikan oleh Tuhan untuk diselamatkan. Maka usaha bersengaja dari jemaat pada Kisah 13:2-4 merupakan momentum yang penting bagi pengutusan misi ke daerah-daerah baru.

\section{Mendidik, Mengajar Orang Yang Sudah Percaya (2:41-47).}

Strategi para Rasul dalam mendorong kemajuan kerohanian jemaat dilakukan melalui pengajaran, persekutuan, ibadah dan mendorong jemaat bersaksi. Kegiatan ini dikelola dengan baik oleh para Rasul atau para pemimpin gereja mula-mula sebagai sarana pendewasaan umat dan membangun spritualitas jemaat, sehingga jemaat ditolong untuk dapat menjadi saksi atau berkat bagi orang di sekitar mereka. Dan nampaknya strategi ini sangat efektif karena melalui kehidupan jemaat banyak orang yang dibawa kepada Tuhan, seperti yang tertulis dalam Kisah 2:47, ... Dan mereka disukai semua orang. Dan tiap-tiap hari Tuhan menambahkan jumlah mereka dengan orang yang diselamatkan. Suatu bentuk pernyataan yang menunjukkan keaktifan jemaat menjadi berkat bagi orang lain dalam lingkungan masing-masing. Jadi dengan adanya pendidikan yang dilakukan gereja mula-mula bagi jemaatnya membuat anggota jemaat menjadi terlibat dengan aktifitas gereja, semua turut terlibat tidak hanya para pelayan atau para rasul tetapi jemaat juga terlibat untuk menjadi berkat dan menjadi pemberita Injil dalam kehidupan mereka sehari-hari. Bahwa semua unsur dalam gereja mula-mula, tidak hanya para rasul tetapi juga termasuk jemaat yang muda itu semua terlibat dalam aktifitas pelayanan. Kesediaan jemaat terlibat dalam berbagai aktifitas pelayanan atau terlibat dalam pekabaran Injil karena mereka diperlengkapi secara rohani melalui pengajaran-pengajaran yang sampaikan kepada jemaat oleh para Rasul. Walaupun mereka masih baru percaya tetapi mereka didorong untuk bertumbuh secara rohani melalui pengajaran, persekutuan dan ibadah bersama. Suatu model gereja yang perlu diteladani oleh jemaat masa kini. 


\section{Pengangkatan Pemimpin Yang Berkualitas Secara Rohani (Kisah 6:3-6)}

Pemimpin mempunyai peran penting dalam pelayanan gereja. Pemimpin yang berkualitas baik akan membuat pelayanan makin maju dan berkembang. Dan para rasul menyadari pokok pikiran ini, karena itu ketika para rasul mengangkat beberapa orang untuk tugas pelayanan tertentu, mereka memilih orang yang baik dan berkualitas secara rohani. Mereka tidak mau memilih para pemimpin yang apa adanya tetapi orang-orang dipandang baik dan berkualitas secara rohani. Pada hal pelayanan yang diemban mereka yang dipilih ini adalah pelayan sederhana yaitu melayani meja. Tetapi meskipun pekerjaan itu sederhana dibutuhkan orang yang berkualitas secara rohani untuk mengerjakannya agar hasilnya baik. Hal ini merupakan prinsip yang sangat penting dalam mengelola pelayanan, bahwa sesederhana apa pun tanggungjawab dalam pelayanan itu, jangan dipercayakan kepada sembarang orang. Ternyata penetapan orang-orang itu berdampak positif bagi gereja mula-mula, ditunjukkan dengan pelayanan gereja makin maju, makin banyak orang yang percaya dan diselamatkan. Pelayanan yang dikelola dengan orang yang tepat dan orang berkualitas akan sangat berpengaruh kepada kemajuan pelayanan atau gereja itu

\section{Senantiasa Taat Kepada Pimpinan Roh Kudus (10:19-20, 13:2-4, 16:6-10)}

Strategi ini merupakan salah satu unsur penting dalam pertumbuhan gereja. Roh Kudus sebagai Roh Penghibur dan sebagai pemimpin orang percaya dalam seluruh hidup, lebih mengetahui apa yang mendesak dan penting dalam strategi gereja. Karena itu gereja mula-mula sangat terbuka dan taat kepada Roh Kudus, sehingga oleh pimpinan Roh Kudus, mereka mengetahui daerah mana yang akan dijangkau dan kepada siapa mereka akan pergi untuk memberitakan Injil. Dengan demikian strategi mereka menjadi tepat dan berhasil, karena Roh Kudus tidak mungkin salah menunjukkan daerah mana yang paling tepat menjadi sasaran pelayanan pemberitaan Injil. Ketika Roh Kudus diberi tempat yang tinggi dalam gereja maka gereja itu akan terus mengalami pimpinanNya. Roh Kudus tidak hanya memberi kuasa rohani kepada gereja itu untuk bersaksi tetapi juga menolong gereja mengerti atau memahami pintupintu yang terbuka bagi pekebaran Injil, sehingga gereja melayani atau memberitakan Injil di tempat-tempat yang tepat.

\section{F. Strategi Pertumbuhan Jemaat Masa Kini}

\section{Rumuskan Tujuan Global Yang Hendak Dicapai}

Tujuan ini sangat penting untuk mengarahkan semua rencana atau program yang akan dibuat. Dengan adanya tujuan, maka semua gerak pelayanan akan terarah dan terkontrol serta terukur. Karena itu pelayanan yang tidak mempunyai tujuan yang jelas akan membuat pelayanan itu tidak terarah dan sulit mengukur kemajuan yang sudah dicapai. Maka dalam usaha mendorong pertumbuhan jemaat masa kini sangat perlu merumuskan tujuan yang jelas yang mau dicapai dalam seluruh pelayanan yang ada. Salah satu tujuan yang penting bagi gereja dalam pelayanannya adalah agar jemaatnya tumbuh menjadi jemaat yang berkualitas murid, yang terlibat dalam pelayanan gerejawi dan pelayanan pekabaran Injil. Jika tujuan sudah ditentukan maka harus ada penetapan waktu pencapaian dan langkah-langkah konkrit untuk mencapai tujuan itu. Karena tujuan tanpa usaha untuk mencapainya itu hanya angan-angan, yang hanya indah untuk dikatakan tetapi dalam kenyataan tidak bernilai. Karena itu tujuan yang sudah ditetapkan harus diperjuangkan untuk mencapainya, dengan program-program 
yang bisa dilakukan. Masa kini terlalu banyak gereja yang hanya melakukan kegiatankegiatan ritual mingguan, perayaan-perayaan tanpa ada program yang berguna bagi kemajuan jemaat.

\section{Rumuskan Berbagai Prinsip Dan Metoda Pembelajaran/Pendidikan Bagi Jemaat}

Jemaat dapat makin maju secara rohani apabila pendidikan yang diberlakukan bagi jemaat berkelanjutan dan intensif. Jemaat mula-mula menikmati pembelajaran dari para rasul, yang diikuti secara tekun, sehingga jemaat mula-mula tumbuh menjadi jemaat yang dewasa dan dapat menjadi berkat serta saksi bagi masyarakat. Pembelajaran yang dilakukan kepada jemaat tidak sekedar melalui ibadah-ibadah bersama dalam bentuk kelompok yang lebih kecil seperti kebaktian rumah tanggga tetapi amat perlu dibuat pembelajaran yang khusus kepada kelompok yang sfesifik. Salah satu contoh, pendidikan yang diberikan kepada para majelis dikelola secara khusus yaitu untuk mempersiapkan mereka menjadi pelayan yang siap menolong para hamba Tuhan (gembala jemaat) dalam menjalankan pelayanan. Dan yang lain, pendidikan khusus diberikan pada para orang tua yang usia pernikahan di bawah lima tahun, dalam kelompok ini mereka ditolong bagaimana membangun rumah tangga dalam masa-masa transisi dengan usia pernikahan yang masih muda dan bagaimana membesarkan anak sejak dini, sehingga mereka sungguh mempersipakan anak-anak mereka menjadi orang yang beriman. Pada bagian lain, sangat perlu memberi pendidikan bagi jemaat yang mempunyai usaha pribadi, agar mereka mengelola usaha secara kristiani, sehingga melalui usaha itu mereka dapat menjadi berkat bagi masyarakat. Karena itu perlu dibuat program yang jelas, sebagai usaha mendidik jemaat agar mereka bertumbuh dan berkembang secara rohani. Program itu disusun bisa berdasarkan kelompok atau umum, misalnya program pendidikan rohani kepada para majelis, para lansia, anak muda, ibu-ibu, para karyawan atau para wirausaha dan lain-lain. Secara umum dilakukan melalui ibadah-ibadah bersama, seperti kebaktian rumah tangga, retreat bersama dan lain-lain. Mungkin gereja masa kini sudah banyak melakukan program-program sejenis, hanya perlu peningkatan pengelolaannya. Karena sering program-program itu hanya berlaku dalam waktu tertentu, sesudah berlangsung beberapa saat, mulai mengalami kemunduran, bahkan ada dari kegiatan itu menjadi hilang dalam gereja. Jadi para pelayan harus menjaga kontiniutas dan peningkatannya sehingga kegiatan itu terus bertahan dan bahkan makin lebih baik dan kreatif.

\section{Tentukan Daerah Atau Suku Sebagai Area Pelayan Misi}

Gereja yang bertumbuh atau berkembang adalah gereja yang memberitakan Injil. Karena itu gereja harus memberitakan Injil. Pemberitaan Injil yang efektif hanya dapat dilaksanakan jika semua jemaat mempunyai beban atau kerinduan yang sama yaitu kerinduan untuk memberitakan Injil. Beban yang sama itu diimplemetasikan dengan menentukan daerah atau suku yang menjadi fokus pemberitaan. Suku itu didoakan bersama dan kemudian ditentukan orang yang akan pergi ke tengah-tengah suku itu. Selanjutnya, jemaat dilatih, dipersiapkan untuk melibatkan diri dalam pemberitaan Injil, sehingga dalam keseharian mereka terlibat dalam pemberitaan Injil, karena tetangga mereka adalah termasuk suku-suku yang terabaikan. 


\section{Bentuk Kelompok Doa}

Gereja mula-mula adalah gereja yang secara nyata mengalami pimpinan Roh Kudus dan oleh keadaan itu jemaat mula-mula bertumbuh secara pesat. Gereja dapat mengalami pimpinan Roh Kudus hanya melalui doa, suatu sikap kebergantungan kepada Allah. Karena itu berdoa secara bersama-sama dan terus menerus adalah cara yang paling efektif untuk melibatkan Roh Kudus dalam mendorong pertumbuhan suatu gereja. Kalau gereja mau melibatkan Roh Kudus, maka doa yang dikelola secara optimal menjadi strategi yang amat penting untuk memacu pertumbuhan gereja. Untuk maksud ini, maka amat perlu dibentuk kelompok-kelompok doa, yang melibatkan jemaat, sehingga jemaat merasa mereka adalah bagian dari pertumbuhan ini. Sekarang ini sangat sedikit gereja memberi perhatian terhadap kegiatan yang penting ini, malah ada gereja yang memandang remeh kegiatan rohani yang sangat berguna ini. Mereka memandang bahwa kebutuhan gereja yang paling utama itu adalah uang. Seolah-olah mereka punya keyakinan bahwa kalau ada uang maka gereja pasti bisa bertumbuh. Karena itu ada banyak gereja sibuk dengan program-program untuk mendatangkan uang, tetapi tidak pernah sibuk dengan doa. Pada hal mereka tidak tahu bahwa gereja bisa bertumbuh hanya oleh kuasa kehadiran Roh Kudus dalam gereja.

\section{Kesimpulan}

Dari penjelasan di atas dapat diambil beberapa kesimpulan yang memberi gambaran tentang inti pokok-pokok pikiran pembahasan tulisan ini. Pertama, bahwa Kisah Para Rasul memberikan prinsip dan strategi tentang pertumbuhan gereja yang dapat dijadikan patron untuk pertumbuhan gereja sepanjang zaman. Kedua, bahwa prinsip dan strategi itu dapat diterapkan secara baik untuk jemaat masa kini dapat bertumbuh jika masukan-masukan di atas diterapkan dalam kehidupan berjemaat masa kini dalam berbagai gereja local. 


\section{Kepustakaan}

Grady, Dick.

1996

Diktat Kuliah Kisah Para Rasul. Bandung, Institut Alkitab Tiranus

Guthrie, Donald 2008

Petersen, Jim. 2009

Peters, George W

2002

Stott, John.

2009

1990

Pengantar Perjanjian Baru, Volume 1. Surabaya. Momentum

Gereja Tanpa Tembok. Jakarta, Pionir Jaya, tahun 2009

Teologi Pertumbuhan Gereja, Malang. Penerbit Gandum Mas

The Living Church. Jakarta. BPK Gunung Mulia

The Message ff Acts. Leicester, Intervarsity Press

Wagner, C. Peter.

1990

Gereja Saudara Dapat Bertumbuh. Malang. Gandun Mas 